\title{
EVALUASI REVITALISASI KAWASAN EKOWISATA WADUK DARMA (STUDI KASUS : REVITALISASI TAHAP 1 WISATA WADUK DARMA DESA JAGARA KECAMATAN DARMA KABUPATEN KUNINGAN JAWA BARAT)
}

\author{
Dhisa Putriady ${ }^{1)}$, B. Irwan Wipranata ${ }^{2)}$, I G. Oka Sindhu Pribadi ${ }^{3)}$
}

\author{
1)Program Studi S1 PWK, Fakultas Teknik, Universitas Tarumanagara, dputriady@gmail.com \\ 2)Program Studi S1 PWK, Fakultas Teknik, Universitas Tarumanagara, irwan wipranata@yahoo.co.uk \\ 3)Program Studi S1 PWK, Fakultas Teknik, Universitas Tarumanagara, okapribadi@cbn.net.id
}

Masuk: 09-08-2021, revisi: 30-08-2021, diterima untuk diterbitkan: 23-10-2021

\begin{abstract}
Abstrak
Jawa Barat dengan potensinya telah mencanangkan pengembangan pariwisata, berdasarkan RIPDA Provinsi Jawa Barat yang menitikberatkan pada perencanaan satu atau lebih destinasi wisata yang telah atau akan menjadi unggulan provinsi tersebut (BAPPEDA Provinsi Jawa Barat, 2018). Sebagai pedoman utama, Revitalisasi wisata Waduk Darma merupakan perwujudan dukungan sepenuhnya terhadap pelestarian obyek wisata sekaligus upaya pemberdayaan potensi sehingga dapat memberikan kontribusi yang lebih signifikan pada penyelenggaraan, pengembangan dan pemberdayaan aset Pemerintah Kabupaten Kuningan. Ekowisata merupakan wisata berorientasi pada lingkungan untuk menjembatani kepentingan perlindungan sumberdaya alam dan industri kepariwisataan. Evaluasi merupakan suatu proses penyediaan informasi mengenai sejauh mana kegiatan tertentu telah dicapai, bagaimana perbedaan pencapaian tersebut dengan suatu standar tertentu untuk mengetahui apakah ada selisih diantara keduanya, serta bagaimana manfaat yang telah dikerjakan bila dibandingkan dengan harapan-harapan yang ingin diperoleh. Tujuannya: 1) Mengetahui potensi ekowisata yang dapat dikembangkan di kawasan wisata Waduk Darma 2) Menganalisis dampak kegiatan revitalisasi terhadap aspek sosial budaya di sekitar Waduk Darma dan 3) Mengevaluasi kesesuaian program revitalisasi tahap pertama wisata Waduk Darma. Metode yang digunakan adalah 1) Analisis kebijakan, 2) Analisis lokasi dan tapak, 3) Analisis wisata dan, 4) Analisis Best Practice. Hasil penelitian 1) Potensi ekowisata di kawasan Waduk Darma berupa panorama alam, pepohonan, areal persawahan, hutan, perairan waduk. Banyak wisatawan berdatangan menikmati ekowisata, 2) Setelah dianalisis, terlihat bahwa revitalisasi Waduk Darma lebih memiliki pengaruh yang besar dan positif terhadap kehidupan sosial budaya masyarakat, dan 3) Revitalisasi tahap pertama sudah sesuai dengan perencanaan, perbandingan kondisi wisata Waduk Darma dahulu dengan sekarang mengalami perbedaan dari sarana/prasarana pariwisata.
\end{abstract}

Kata kunci: Ekowisata; Evaluasi; Revitalisasi; Waduk Darma.

\begin{abstract}
West Java with its potential has launched tourism development based on the RIPDA of West Java Province which focuses on planning one or more tourist destinations that have been or will become the flagship of the province. As the main guideline, the tourism revitalization of the Waduk Darma is a manifestation of full support for the preservation of tourism objects as well as efforts to empower potential so that they can make a more significant contribution to the implementation, development and empowerment of the Kuningan Regency Government assets. Ecotourism is environmentally oriented tourism to bridge the interests of natural resource protection and the tourism industry. Evaluation is a process of providing information about the extent to which certain activities have been achieved, how the achievement differs from a certain standard to find out whether there is a difference between the two, and how the benefits that have been carried out are compared to the expectations to be obtained. The objectives are: 1) Knowing the ecotourism potential that can be developed in the Waduk Darma tourist area 2) Analyzing the impact of revitalization activities on socio-cultural aspects around the Darma Reservoir and 3) Evaluating the suitability of the first phase revitalization program for Waduk Darma tourism. The methods used are 1) Policy analysis, 2) Location and site analysis, 3) Tourism analysis and, 4) Best Practice analysis. Research results 1) The
\end{abstract}


potential for ecotourism in the Darma Reservoir area is in the form of natural panoramas, trees, rice fields, forests, reservoir waters. Many tourists come to enjoy ecotourism, 2) After being analyzed, it can be seen that the revitalization of the Darma Reservoir has a greater and positive influence on the socio-cultural life of the community, and 3) The first phase of revitalization is in accordance with the planning, the comparison of the tourism conditions of the Darma Reservoir before and now is experiencing differences. of tourism facilities/infrastructure.

Keywords: Ecotourism; Evaluation; Revitalization; Waduk Darma

\section{PENDAHULUAN Latar Belakang}

Ada yang perlu dikaji dari wisata Waduk Darma. Meski cukup ramai menjadi tujuan wisata keluarga, namun inovasi penanganannya saat ini menjadi pusat perhatian. Sebagian warga sekitar, tidak sedikit yang bahagia dengan penataan wisata Waduk Darma (Pemda Provinsi Jawa Barat, 2020). Pemandangan yang sebelumnya hanya apa adanya, kini tidak lagi hanya sekedar pemandangan alam biasa namun secara bertahap berubah menyerupai area wisata berkelas, tentunya akan berkalilipat keindahannya. Wajar jika warga sekitar penuh harap mempunyai kemajuan serupa, baik secara sosial maupun komersial. Secara sosial, warga sekitar akan banyak memiliki pola fikir baru, budaya baru, komunitas baru, dsb. Secara komersial, penghasilan warga, pelaku usaha di lokasi wisata maupun warga sekitar akan lebih baik. Seiring dengan banyaknya peluang bisnis dan wirausaha baru bagi UKM, termasuk lowongan kerja yang bisa dimanfaatkan oleh warga sekitar.

Jawa Barat dengan potensinya telah mencanangkan pengembangan pariwisata berdasarkan RIPDA Provinsi Jawa Barat yang menitikberatkan pada perencanaan satu atau lebih destinasi wisata yang telah atau akan menjadi unggulan provinsi tersebut. Pengembangan kawasan wisata utama provinsi ini diharapkan berdampak ganda terhadap pengembangan kawasan wisata dan kawasan lain di Jawa Barat (BAPPEDA Provinsi Jawa Barat, 2018). Sebagai pedoman utama, RIPDA Jawa Barat memuat (1) konsep pengembangan pariwisata Jawa Barat berdasarkan perencanaan dan pendekatan strategis pengembangan pariwisata di Jawa Barat, (2) mengidentifikasi kawasan wisata unggulan. Provinsi Jawa Barat dan kawasan pariwisata unggulan kabupaten/kota, dan (3) arah kebijakan dan strategi pengembangan kepariwisataan di Jawa Barat dan indikasi milestone kegiatan pembangunan pariwisata di masing-masing kawasan wisata unggulan provinsi.

Secara sosiologis kawasan Waduk Darma terkenal dengan masyarakatnya yang religius. Wajar saja jika keberadaan wisata yang tengah digarap sebagai destinasi wisata Internasional ini dikhawatirkan akan mengganggu ketentraman warga sekitar. Praduga yang tak bisa disalahkan juga, jika sebagian masyarakat mengkhawatirkan akan adanya tindakan yang tidak sesuai dari pihak luar sebagai konsekwensi datangnya pengunjung yang kian beragam. Tidak heran ada sebagian warga sekitar yang sampai saat ini masih melakukan audiensi dengan pemerintah untuk meminta kejelasan terkait kebijakan yang kelak akan dikeluarkan, pro atau tidak terhadap rakyat. Patut kita apresiasi kiranya perjuangan ini, minimal akan ada penyeimbang dari berbagai pihak untuk tetap menjaga kenyamanan dan ketertiban kehidupan masyarakat di sekitar kawasan Waduk Darma. Tidak saja dari aspek agama, namun sosial dan budaya. Akan selalu ada resiko untuk sebuah perubahan. Semoga saja pembangunan wisata Waduk Darma yang diharapkan dapat memberi dampak kemajuan bukan saja bagi pemerintah Kuningan atau Propinsi Jawa Barat, yang paling penting adalah warga sekitar kawasan Waduk Darma tetap menjadi prioritas.

Revitalisasi merupakan cara untuk meningkatkan nilai sesuatu yang dianggap sudah tidak berfungsi dengan baik, merupakan jawaban atas terbengkalainya sebuah aset terutama aset yang dimiliki oleh pihak Pemerintah (Wardani, 2018). Konsep ini sering diimplementasikan 
sebagai salah satu solusi untuk menata kembali aset pemerintah yang sudah lama berkurang nilai kemanfaatannya, terutama dalam konteks Pariwisata.

Dengan revitalisasi maka aset obyek wisata akan dikenal kembali dengan beberapa perubahan dan perbaikan, diharapkan popularitasnya meningkat sehingga akan berdampak langsung secara ekonomis pada pendapatan daerah. Program revitalisasi merupakan bagian dari strategi dan program pembangunan kepariwisataan yang dilaksanakan oleh Pemerintah Kabupaten Kuningan. Revitalisasi wisata Waduk Darma merupakan perwujudan dukungan sepenuhnya terhadap pelestarian obyek wisata sekaligus upaya pemberdayaan potensi sehingga dapat memberikan kontribusi yang lebih signifikan pada penyelenggaraan, pengembangan dan pemberdayaan aset Pemerintah Kabupaten Kuningan (Pemda Kabupaten Kuningan, 2011). Revitalisasi wisata Waduk Darma juga membangun sebuah kondisi, dimana kemitraan bersama masyarakat dinomorsatukan. Manfaatnya bukan hanya untuk Pemerintah Kabupaten Kuningan, PDAU, masyarakat juga harus ikut merasakan.

Revitalisasi Waduk Darma merupakan salah satu perwujudan kebijakan strategi Pemerintah Provinsi Jawa Barat seperti yang tertuang dalam Rencana Strategis pembangunan Jawa Barat di kepemimpinan Gubernur Ridwan Kamil yang akan menyentuh segala dimensi untuk memajukan Jawa Barat sesuai visi : Jawa Barat Juara Lahir Batin dengan Inovasi dan Kolaborasi (nilai religius, nilai bahagia, nilai adil, nilai kolaboratif dan nilai inovatif) (BAPPEDA Provinsi Jawa Barat, 2018). Revitalisasi Waduk Darma terdiri dari 3 tahap yaitu : 1) Tahap pertama berupa kegiatan pekerjaan persiapan, pembangunan gate-1, gazebo ( 3 unit), landscape (taman), plaza A dan tempat parkir; 2) Tahap kedua berupa kegiatan pembangunan masjid, Gedung serbaguna, kantor pengelola, foodcourt, gate-2, cottage (11 unit), camping ground (9 unit), gazebo (4 unit), ground tank, ruang genset, menara air, landscape (taman), plaza, tempat parkir, wahana bermain, dan kolam retensi; 3) Tahap 3 berupa pembangunan boardwalk dan sculpture. Revitalisasi tahap pertama yang sudah selesai di bulan Juni-Desember 2019 berfokus di bagian darat. Tahap pertama revitalisasi yang telah selesai dilaksanakan dan telah dibuka kembali pada 21 Juni 2020 lalu setelah ditutup akibat pademi COVID-19 (kuninganmass.com, 2020).

Tahap pertama yang kini sudah selesai diantaranya: gerbang utama/gate, tempat parkir dan tiket, mushola, panggung serbaguna, warung, cottage, saung/gazebo, kantor pengelola, plaza, dan wahana permainan. Selain itu pihak pengelola membangun spot foto penambahan spot foto dari kayu dan bambu bertingkat yang terletak di pinggir waduk. Dampak pandemi covid-19 ternyata berimbas ke sektor infrastruktur, seperti pembangunan revitalisasi Waduk Darma tahap dua untuk sementara dihentikan. Untuk tahap dua dan tiga akan dilaksanakan kembali pada tahun 2021-2022 sebagian berfokus ke darat dan lainnya berfokus di pembangunan tengah waduk atau kawasan air. Jika revitalisasi Waduk Darma berjalan mulus akan menimbulkan efek domino bagi peningkatan perekonomian masyarakat, ekonomi kreatif, oleh-oleh, angkutan umum, kuliner dan gerakan ekonomi. Meskipun revitalisasi sepenuhnya belum selesai, revitalisasi Waduk Darma tahap pertama sudah mulai menampakan hasil. Namun diperlukan kajian akademis untuk menganalisis, serta mengevaluasi proses revitalisasi tahap pertama agar revitalisasi tahap dua dan tiga dapat berjalan secara efektif, efisien, dan sesuai yang diharapkan oleh semua pihak.

Penelitian ini diharapkan menjadi acuan sesuai konsep revitalisasi selain itu meninjau kesesuaian konsep ekowisata dalam menggambarkan dan menjelaskan proses pelaksanaan revitalisasi tahap pertama di wisata Waduk Darma. Sehingga hal-hal positif dalam proses tersebut dapat dipertahankan bahkan ditingkatkan, serta hal-hal yang dianggap kurang akan segera diperbaiki. 


\section{Rumusan Permasalahan}

Berdasarkan latar belakang di atas yang akan dibahas secara terperinci yaitu mengenai potensi ekowisata, dampak kegiatan revitalisasi terhadap aspek sosial budaya di sekitar dan evaluasi proses pelaksanaan revitalisasi tahap pertama dengan perencanaan yang sudah ada di wisata Waduk Darma, Kabupaten Kuningan.

\section{Tujuan}

Adapun tujuan penelitian ini adalah untuk mengetahui ekowisata yang dapat dikembangkan di kawasan wisata Waduk Darma, menganalisis dampak kegiatan revitalisasi terhadap aspek sosial budaya di sekitar Waduk Darma, dan mengevaluasi kesesuaian program revitalisasi tahap pertama wisata Waduk Darma

\section{KAJIAN LITERATUR}

\section{Waduk}

Waduk atau reservoir adalah danau alam atau danau buatan, kolam penyimpan atau pembendungan sungai yang bertujuan untuk menyimpan air. Waduk secara umum merupakan tempat di permukaan bumi yang digunakan untuk menampung air pada saat terdapat kelebihan air atau pada saat musim hujan sehingga air dapat digunakan pada saat musim kemarau. Sumber waduk terutama dari aliran permukaan yang dikombinasikan dengan air hujan langsung. Reservoir bisa timbul baik alami maupun buatan. Waduk buatan dibangun dengan membuat bendungan dan aliran air selanjutnya sampai waduk terisi penuh (Purboseno, 2013)

Dalam arahan konsep penataan kawasan dan bangunan sekitar waduk, harus dilakukan pembagian zona berdasarkan fungsinya. Pembagian zona terbagi menjadi Zona Inti (A), Zona Transisi/Greenbelt (B) dan Zona Terbangun (C) sebaiknya dikelola oleh suatu Badan Otorita yang merupakan satu kesatuan wilayah ekosistem Waduk Darma.

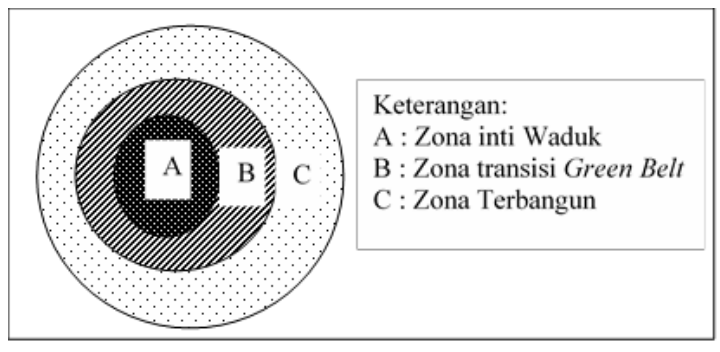

Gambar 1. Zoning Kawasan Waduk

Sumber : ejournal.undip.ac.id

\section{Pariwisata}

Obyek wisata atau yang lebih populer dengan sebutan Obyek dan Daya Tarik Wisata (ODTW) yang biasa disebut dengan "tourist atraction", adalah segala sesuatu yang menarik orang atau sekelompok orang untuk mengunjungi suatu daerah (Yoeti, 2014). Daya tarik wisata dalam hal ini selalu dikaitkan dengan konsep "produk" dari kegiatan industri pariwisata. Dalam kegiatan wisata, obyek dan daya tarik wisata (tourist interest) merupakan elemen penentu. Kedua elemen tersebut menarik minat wisatawan mancanegara atau domestik yang ingin berkunjung ke suatu destinasi wisata. Menurut definisi dalam UU No. 10 Tahun 2009, Daya Tarik Wisata adalah segala sesuatu yang memiliki keunikan, keindahan, dan nilai yang berupa keanekaragaman kekayaan alam, budaya, dan hasil buatan manusia yang menjadi sasaran atau tujuan kunjungan wisatawan (Kemenhumkam, 2009). Menurut definisi dalam UU No. 10 Tahun 2009, Kawasan Strategis Pariwisata adalah kawasan yang memiliki fungsi utama pariwisata atau memiliki potensi untuk 
pengembangan pariwisata yang mempunyai pengaruh penting dalam satu atau lebih aspek, seperti pertumbuhan ekonomi, sosial dan budaya, pemberdayaan sumber daya alam, daya dukung lingkungan hidup, serta pertahanan dan keamanan. Kawasan pariwisata adalah kawasan dengan luas tertentu yang dibangun atau disediakan untuk memenuhi kebutuhan pariwisata (Kemenhumkam, 2009).

\section{Ekowisata}

Ekowisata pertama kali dikenalkan pada tahun 1990 oleh organisasi The Ecotourism Society, sebagai perjalanan ke daerah-daerah yang masih alami yang dapat mengkonservasi lingkungan dan memelihara kesejahteraan masyarakat setempat (Blangy dan Wood, 1993 dalam Lindberg dan Hawkins, 1993). Ekowisata merupakan wisata berorientasi pada lingkungan untuk menjembatani kepentingan perlindungan sumberdaya alam dan industri kepariwisataan (META, 2002). Ekowisata dapat menciptakan dan memenuhi keinginan akan alam, memanfaatkan potensi pariwisata untuk konservasi dan pembangunan, serta mencegah dampak negatif terhadap ekosistem, budaya dan keindahan (Lindberg dan Hawkins, 1993). Semula ekowisata dilakukan oleh wisatawan pecinta alam yang menginginkan daerah tujuan wisata tetap utuh dan lestari, disamping budaya dan kesejahteraan masyarakatnya tetap terjaga.

Ekowisata berkembang karena banyak digemari oleh wisatawan. Wisatawan ingin berkunjung ke daerah alami yang menciptakan kegiatan bisnis (Pudjiwaskito, 2005). Ekowisata kemudian diartikan sebagai bentuk baru perjalanan bertanggung jawab ke kawasan alam dan petualangan yang dapat menciptakan industri pariwisata (Fandeli, 2000). Sumber daya ekowisata terdiri dari sumber daya alam dan manusia yang dapat diintegrasikan ke dalam satu komponen pemanfaatan pariwisata yang terintegrasi. Berdasarkan konsep pemanfaatannya, pariwisata dibedakan menjadi tiga kelompok yaitu (Fandeli, 2000; META, 2002; dan Yulianda, 2007):

a. Wisata alam (nature tourism), merupakan aktivitas wisata yang ditujukan pada pengalaman terhadap kondisi alam atau daya tarik panoramanya.

b. Wisata budaya (cultural tourism), merupakan wisata dengan kekayaan budaya sebagai obyek wisata dengan penekanan pada aspek pendidikan.

c. Ekowisata (Ecotourism, green tourism atau alternative tourism), merupakan wisata berorientasi pada lingkungan untuk menjembatani kepentingan perlindungan sumberdaya alam/lingkungan dan industri kepariwisataan.

Dalam kaitannya dengan ekowisata, Damanik, Janianton dan Weber (2006) menyusun tiga konsep dasar tentang ekowisata yaitu sebagai berikut : Pertama, perjalanan outdoor dan di kawasan alam yang tidak menimbulkan kerusakan lingkungan. Kedua, wisata ini mengutamakan penggunaan fasilitas yang diciptakan dan dikelola oleh masyarakat kawasan wisata. Ketiga, perjalanan wisata ini menaruh perhatian besar pada lingkungan alam dan budaya lokal.

Prinsip ekowisata merupakan berbagai prinsip yang mengatur untuk menyatukan konservasi lingkungan hidup, pengembangan masyarakat dan wisata yang berkelanjutan, berjalan seiringan. Hal ini berarti bahwa para pihak yang melaksanakan, berpartisipasi dalam ekoturisme harus menjalankan kriteria dan prinsip tersebut. Prinsip ekowisata adalah sebagai berikut:

a. Meminimalkan dampak fisik, sosial, perilaku, psikologis.

b. Membangun kesadaran lingkungan, budaya dan rasa hormat.

c. Memberikan pengalaman positif bagi pengunjung dan tuan rumah.

d. Memberikan manfaat keuangan langsung bagi konservasi atau pelestarian lingkungan hidup.

e. Menghasilkan keuntungan finansial bagi masyarakat lokal, industri swasta.

f. Memberikan pengalaman interpretatif yang mengesankan bagi pengunjung untuk meningkatkan sensitivitas terhadap iklim politik, lingkungan, sosial tempat tujuan wisata. 
g. Membangun, mengoperasikan fasilitas atau infrastruktur dengan meminimalkan dampak lingkungan.

h. Mengakui hak-hak, keyakinan spiritual komunitas adat dan memberdayakan mereka (Damanik, Janianton dan Weber, 2006).

Konsep ekowisata juga harus berprinsip pada :

a. Mendidik wisatawan agar mengetahui pentingnya menjaga lingkungan.

b. Kawasan tersebut mendapat hasil dari profit yang didapatkan dari daya tarik ekowisata. Partisipasi masyarakat dalam perencanaan dan pengelolaan, sehingga dalam pengembangan dan pengawasannya masyarakat ikut terlibat dan menerima dampak.

c. Penghasilan masyarakat artinya profit yang didapatkan masyarakat atas usaha dalam pengembangan dan pengelolaannya yang didapatkan dari kunjungan wisatawan.

d. Menjaga keharmonisan dengan alam artinya segala pembentukan infrastruktur tidak merusak lingkungan.

e. Daya dukung lingkungan artinya dalam pengembangan ekowisata harus tetap memperhitungkan dan memperhatikan daya dukung lingkungan.

f. Peluang penghasilan yang didapatkan negara porsinya cukup besar (Damanik, Janianton dan Weber, 2006).

\section{Revitalisasi}

Revitalisasi merupakan sebuah cara untuk meningkatkan nilai sesuatu yang dianggap sudah tidak berfungsi dengan baik. Pada prinsipnya Revitalisasi merupakan jawaban atas terbengkalainya sebuah aset terutama dalam hal ini aset yang dimiliki oleh pihak Pemerintah (Budihardjo, Eko \& Sidharta, 1989). Konsep ini sering diimplementasikan sebagai salah satu solusi untuk memunculkan kembali aset pemerintah yang sudah lama berkurang nilai kemanfaatannya, terutama dalam konteks Pariwisata. Dengan Revitalisasi maka aset atau dalam hal ini sebuah objek wisata akan muncul kembali dengan beberapa perubahan dan perbaikan, dan diharapkan popularitasnya meningkat sehingga akan berdampak langsung secara ekonomis pada pendapatan daerah.

Tahapan pelaksanaan revitalisasi dalam proses konservasi (Budihardjo, Eko \& Sidharta, 1989), yaitu:

a. Penjadwalan dan pentahapan rencana fisik

b. Pemilihan usulan-usulan, penggunaan-penggunaan yang sesuai dengan nilai-nilai lingkungan dan layak dilaksanakan.

c. Menafsirkan kemungkinan kelangsungan perencanaan dalam pelaksanaan terhadap hubungan tingkah laku fisik dan fungsi atau penggunaan serta budayanya.

d. Pengelolaan terhadap susunan/tahapan pelaksanaan rencana fisik

e. Pengendalian terhadap lokasi dengan pemeriksaan yang rutin terhadap pengaruh-pengaruh pada fisik dan sosial budayanya

f. Estimasi perubahan/perbaikan oleh pengaruh kegiatan yang akan datang.

Revitalisasi Waduk Darma merupakan salah satu perwujudan kebijakan strategi Pemerintah Provinsi Jawa Barat seperti yang tertuang dalam Rencana Strategis pembangunan Jawa Barat di kepemimpinan Gubernur Ridwan Kamil yang akan menyentuh segala dimensi untuk memajukan Jawa Barat sesuai visi : Jawa Barat Juara Lahir Batin dengan Inovasi dan Kolaborasi (nilai religius, nilai bahagia, nilai adil, nilai kolaboratif dan nilai inovatif) (BAPPEDA Provinsi Jawa Barat, 2018).

\section{Evaluasi}

Evaluasi merupakan suatu proses penyediaan informasi mengenai sejauh mana kegiatan tertentu telah dicapai, bagaimana perbedaan pencapaian tersebut dengan suatu standar 
tertentu untuk mengetahui apakah ada selisih diantara keduanya, serta bagaimana manfaat yang telah dikerjakan bila dibandingkan dengan harapan-harapan yang ingin diperoleh (Edvardsson dan Anderson, 2005).

Adapun kriteria lain dalam rangka mengevaluasi suatu kebijakan adalah :

a. Efisiensi : Dikatakan efisien jika hasil (output atau outcomes) lebih besar (berarti) dari pada biaya implementasi serta penegakan untuk kebijakan tersebut. Yang digunakan adalah kriteria "cost-effectiveness", suatu kebijakan bersifat efisien maka "costeffevtiveness" tetapi tidak sebaliknya.

b. Keadilan : Pembagian (penyebaran) keuntungan yang diperoleh dari suatu kebijakan diantara kelompok masyarakat (stakeholders).

c. Insentif untuk perbaikan : Kebijakan yang baik adalah yang mendorong para "stakeholders" mencari dan menerapkan pendekatan atau teknologi untuk perbaikan.

d. Kemudahan untuk penegakan hukum : Dapat atau tidaknya kebijakan diimplementasikan secara ditegakkan.

e. Pertimbangan moral : Dapat disimpulkan evaluasi kebijakan merupakan proses yang dilakukan mengukur sejauhmana kebijakan mencapai hasil yang ditetapkan sebelumnya. Pengukuran didasar pada tercapainya indikator pelaksana kebijakan yang diukur dari sisi efisiensi, efektivitas, maupun outcome kebijakan (Edvardsson dan Anderson, 2005). 


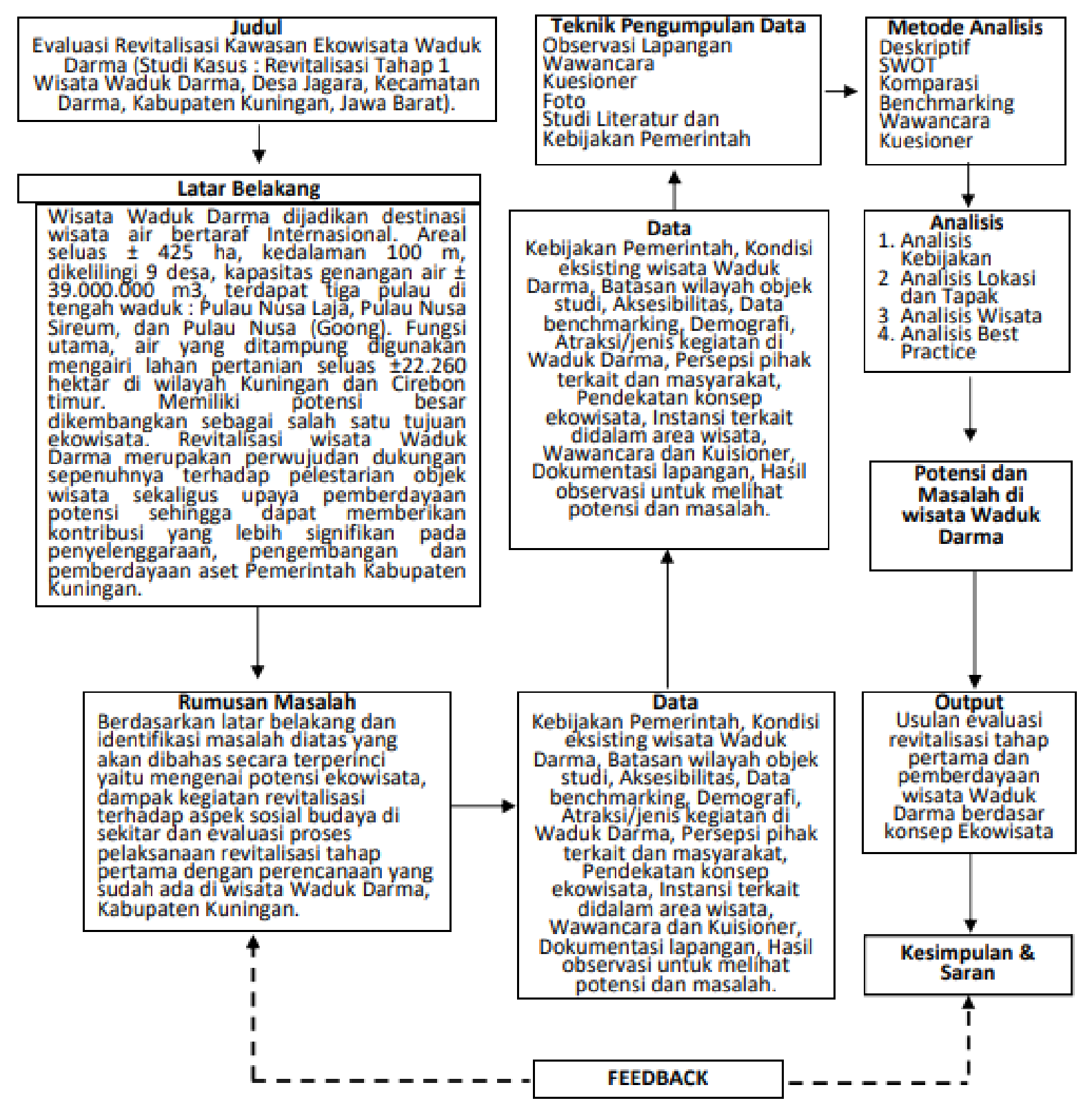

Gambar 2. Bagan Kerangka Pikir Sumber: Olahan Penulis 


\section{METODE}

\section{Variabel Penelitian}

Variabel penelitian dilakukan dengan variabel kualitatif dan variabel kuantitatif. Variabel kualitatif digunakan penulis untuk mencirikan unsur deskripsi atau narasi tekstual dan Variabel Kuantitatif yang digunakan penulis untuk mencirikan numeric atau angka.

a. Variabel kualitatif : Analisis Kebijakan, Analisis Lokasi Tapak dan Analisis Wisata.

b. Variabel kuantitatif : Analisis Wisata dan Analisis Benchmarking

\section{Metode Pengumpulan Data}

a. Kuesioner: Menerima informasi secara langsung, dengan bertanya kepada beberapa pengunjung. Data kuesioner didapat untuk mengetahui persepsi pengunjung dan keinginannya terhadap objek studi.

b. Observasi Lapangan: Observasi atau pengamatan langsung di lapangan meliputi kegiatan pemusatan perhatian terhadap objek studi dengan menggunakan seluruh alat indera.

c. Wawancara: Pengumpulan data yang dilakukan dengan mengadakan tanya jawab dengan informan yang diteliti untuk mendapatkan data yang diperlukan. Tujuannya adalah berusaha menggali informasi dari informan secara mendalam serta mengetahui apa yang terkandung dalam pikiran dan hati orang lain, yaitu hal-hal yang tidak dapat diketahui melalui observasi.

d. Foto: Fotografi lebih banyak digunakan sebagai alat penelitian karena dapat digunakan untuk berbagai keperluan. Foto-foto tersebut memberikan data yang sangat berharga yang sering digunakan untuk mempelajari aspek subjektif, dan hasilnya sering kali menjadi sasaran analisis induktif. Ada dua kategori foto yang dapat digunakan dalam penelitian kualitatif, yaitu foto yang diambil oleh orang dan foto yang dibuat oleh peneliti sendiri.

e. Studi Literatur: Studi literatur adalah cara yang dipakai untuk menghimpun data-data atau sumber-sumber, berhubungan dengan topik yang diangkat dalam penelitian ini. Studi literatur bisa didapat dari berbagai sumber, jurnal, buku dokumentasi, internet dan pustaka (Sugiyono, 2018).

\section{Metode Analisis}

a. Metode Deskriptif: Menggambarkan suatu hal menggunakan data-data yang telah dikumpulkan, kemudian disajikan dalam bentuk yang ringkas dan mudah dipahami.

b. Metode SWOT: Membandingkan antara faktor eksternal dengan factor internal yang ada di wisata Waduk Darma.

c. Metode Komperatif: Analisis komparatif merupakan metode penelitian yang sifatnya membandingkan, yang dilakukan untuk membandingkan masing-masing tentang konsep wisata.

d. Metode Benchmarking: Membandingkan kinerja terhadap aktivitas atau kegiatan yang sejenis baik yang internal maupun eksternal.

e. Wawancara: Percakapan yang dilakukan oleh 2 orang atau lebih, yang berlangsung antara narasumber dan pewawancara. Tujuan dari wawancara adalah untuk mendapatkan informasi.

f. Kuesioner: Disini penulis memakai sampling snowball untuk menyebarkan kuesioner yang ada kepada masyarakat sekitar, pengelola dan pengunjung obyek wisata (Neuman, 2013).

\section{DISKUSI DAN HASIL}

\section{Analisis Kebijakan}

Waduk Darma juga digambarkan kedalam Peta Rencana Pola Ruang dan Peta Kawasan Strategis, berikut Peta tersebut : 


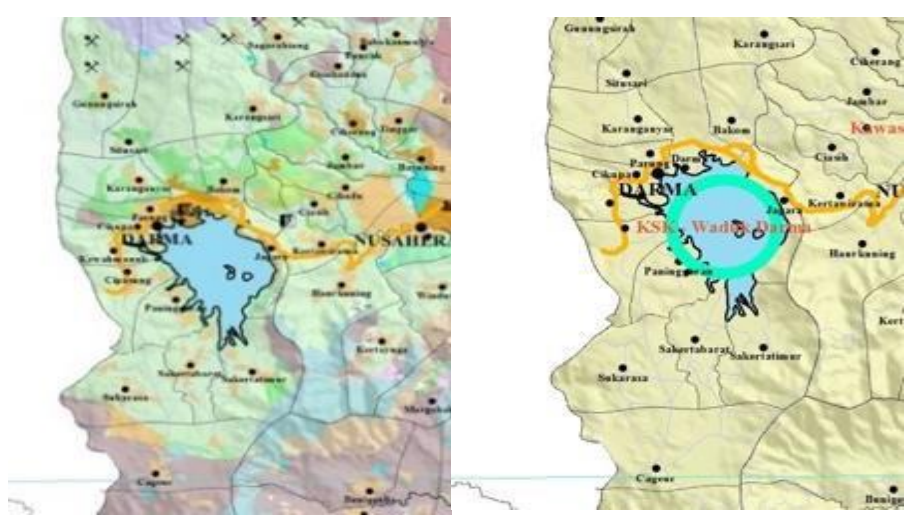

Peta Rencana Pola Ruang (b) Peta Kawasan Strategis

Gambar 3. Peta Rencana Kabupaten Kuningan

Sumber: RTRW Kabupaten Kuningan

Rencana Tata Ruang Kabupaten Kuningan telah ditetapkan melalui Peraturan Daerah Kabupaten Kuningan Nomor 26 Tahun 2011 tentang Rencana Tata Ruang Wilayah (RTRW) Kabupaten Kuningan tahun 2011-2031. Salah satu kebijakan tata ruang yang bersifat strategis dalam revisi RTRW adalah merencanakan Kawasan Strategis Kabupaten (KSK) dari sudut kepentingan ekonomi berupa KSK Pariwisata Waduk Darma dan sekitarnya serta KSK dari sudut kepentingan fungsi dan daya dukung lingkungan hidup. Kebijakan meliputi keseluruhan wilayah sekitar Waduk Darma, diharap mendukung segala bentuk wisata yang akan dicanangkan pemerintah (Pemda Kabupaten Kuningan, 2011).

Kondisi eksisting yang ada saat ini terbilang sesuai dengan rencana yang dicanangkan pemerintah. Waduk Darma yang tercatat dalam buku inventaris Pemprov Jawa Barat dan pengelolaannya oleh Pemerintah Pusat melalui Kementrian PUPR. Sesuai keinginan Gubernur menjadikan Waduk Darma pusat pariwisata dan kebudayaan unggulan di Jawa Barat. Dengan revitalisasi akan diintegrasikan dengan desa-desa penyangga Waduk Darma. Desa-desa sekitar Waduk Darma akan turut menikmati dan tidak hanya sekedar jadi penonton sekaligus meningkatkan PAD Kabupaten Kuningan.

Berikut merupakan peta rencana revitalisasi tahap pertama :

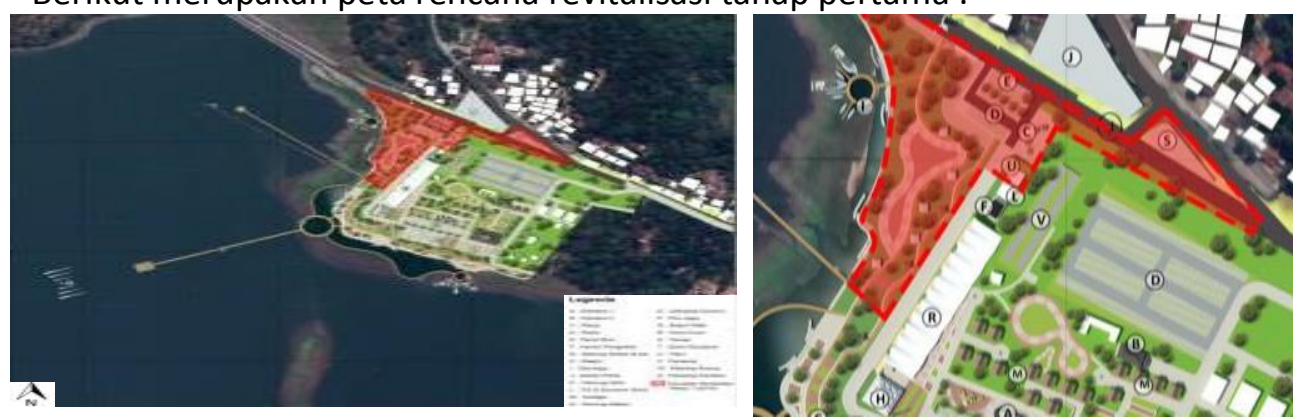

Gambar 4. Rencana Revitalisasi Tahap Pertama Sumber : (PDAU Kabupaten Kuningan, 2019)

Sesuai rencana, revitalisasi tahap pertama yang sudah selesai diantaranya : gate-1, gazebo (3 unit), landscape (taman), plaza A dan tempat parkir. 
Tabel 1. Perbandingan Kondisi Eksisting dan Rencana Revitalisasi Tahap 1

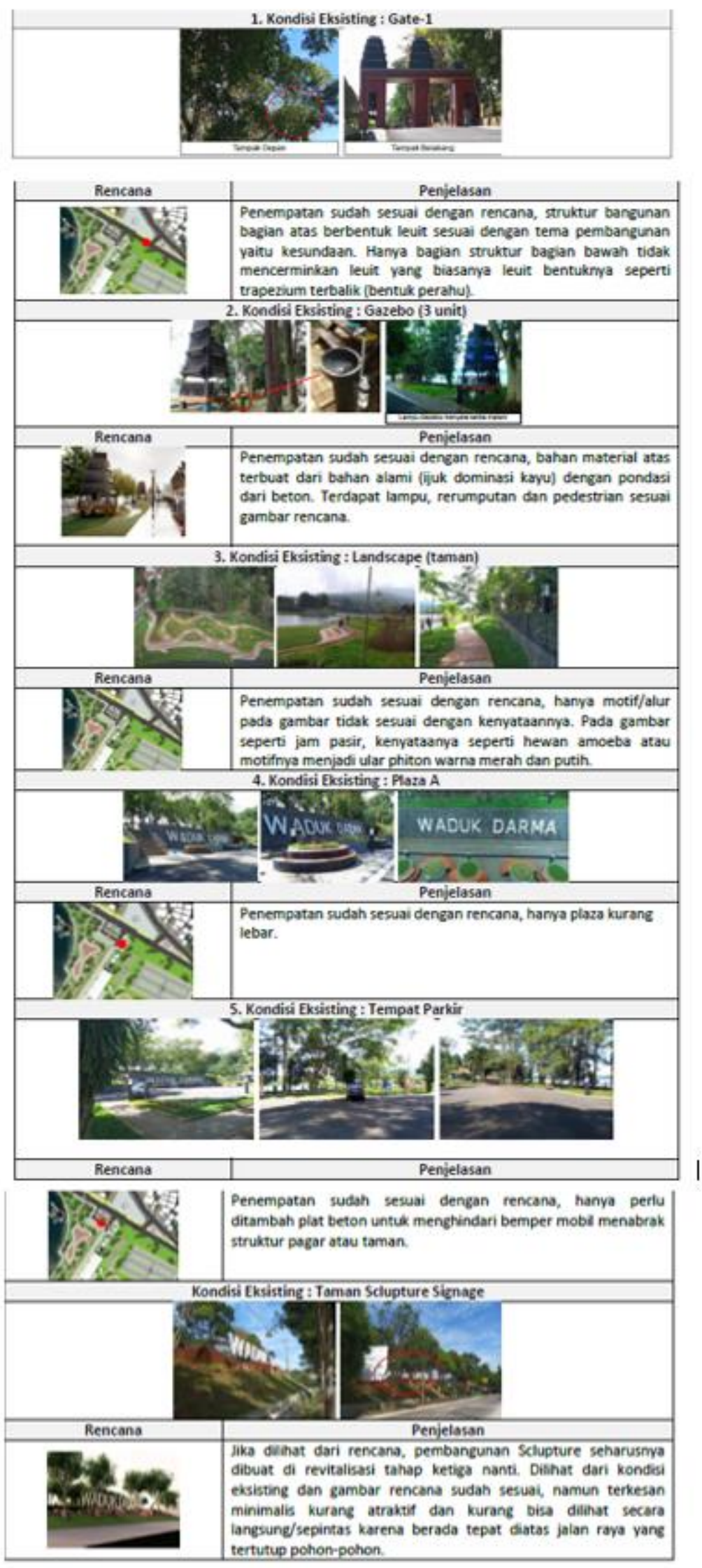


Dapat disimpulkan revitalisasi tahap pertama sudah sesuai dengan rencana yang ada. Didukung dengan banyaknya orang yang datang setelah tempat wisata dibuka kembali. Terlihat juga saat penulis melakukan survey dan kegiatan rekreasi disana. Kebijakan, peraturan dan rencana juga sudah sesuai dan masuk kategori baik. Dapat dijadikan tolak ukur ketika dibandingkan dengan kondisi eksisting dan segala potensi yang ada. Kondisi wisata Waduk Darma dahulu dengan sekarang mengalami perbedaan, mulai dari sarana/prasarana pariwisata. Dampak yang ditimbulkan revitalisasi tahap pertama dari segi bangunan menjadi lebih bagus, lebih bersih, lebih nyaman dan lebih indah. Perlu adanya pemeliharaan sarana/prasarana yang sudah direvitalisasi pada tahap 1 yaitu gazebo supaya tidak terjadi vandalisme. Pemeliharaan kebersihan dan keindahan taman/jogging track yang kontinu dan penunjuk arah (signage) yang belum memadai. Hal ini sesuai dengan hasil kuesioner persepsi terhadap infrastruktur wisata wisata dilihat dari parkir sebagian besar cukup (44\%), warung Sebagian besar cukup (50\%), dan pusat informasi sebagian besar cukup (30\%).

\section{Analisis Lokasi dan Tapak}

Objek studi yaitu wisata Waduk Darma yang terletak di sebelah barat daya dari Kota Kuningan, tepatnya di Desa Jagara-Kecamatan Darma dan pada lintasan jalan raya Cirebon-KuninganCiamis. Jarak wisata Waduk Darma $\pm 12 \mathrm{~km}$ dari kota Kuningan dan $\pm 37 \mathrm{~km}$ dari kota Cirebon. Posisi Waduk Darma secara geografis berada di titik koordinat koordinat $7^{\circ} 0^{\prime} 26^{\prime \prime} \mathrm{S}, 108^{\circ} 24^{\prime} 50^{\prime \prime}$ E. Waduk Darma menempati areal seluas \pm 425 ha serta kedalaman $\pm 100 \mathrm{~m}$ yang dikelilingi oleh 9 desa. Dengan kapasitas genangan air maksimal $\pm 39.000 .000 \mathrm{m3}$. Memiliki pemandangan alam hijau yang dikelilingi lembah serta bukit dan tiga pulau kecil di tengah waduk. Berikut batas administrasi objek studi :

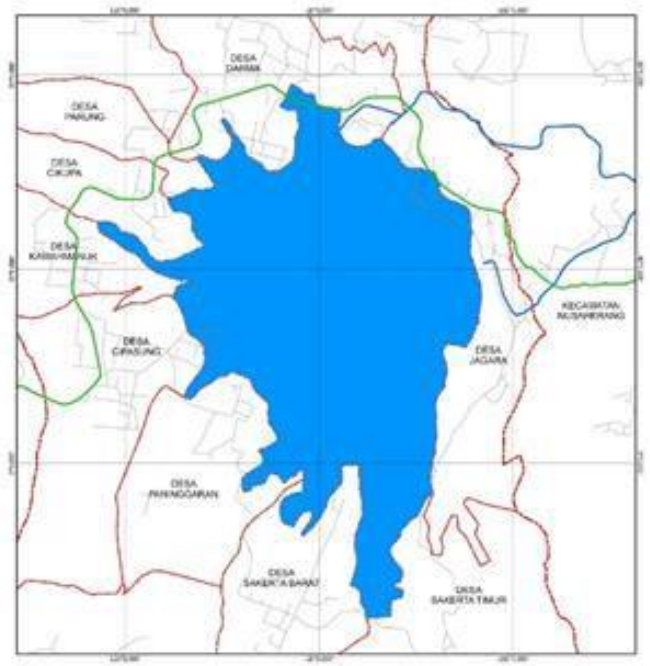

Gambar 5. Posisi Administrasi Waduk Darma Sumber : Googlemaps

Sebelah Barat : Desa Cipasung, Desa Parung, Desa Cikupa, Desa Kawahmanuk Sebelah Timur : Desa Jagara Sebelah Selatan : Desa Paninggaran, Desa Sakerta Barat, Sakerta Timur Sebelah Utara : Desa Darma Dapat dilihat bahwa objek studi berada dikawasan yang cukup strategis. 
Aksesibilitas menuju wisata Waduk Darma cukup didukung dengan sarana yang memadai, beraneka pilihan transpotasi untuk dapat mengakses Waduk Darma juga cukup mudah. Melihat dari semua kemudahan akses yang didukung oleh moda transpotasi, tetapi pada saat dilapangan mudah menemukan pintu masuk menuju Waduk Darma dikarenakan pintu gerbang memasuki obyek wisata cukup terlihat dari jalan utama dari arah utara, sedangkan dari arah selatan harus memutar dulu melalui jalan lingkar (jalan baru), selain itu kurangnya papan signage yang belum ada disepanjang jalan untuk memberi informasi keberadaan dari Waduk Darma tersebut. Lokasi wisata Waduk Darma memiliki daerah yang cukup strategis jika dilihat dengan kedekatan antara pusat kegiatan dan fasilitas umum (area vital) yang ada dengan radius $15 \mathrm{Km}$. Kedekatan wisata Waduk Darma dengan sarana/fasilitas umum yang ada amat sangat mendukung objek studi dalam melakukan revitalisasi berbasis ekoturism. Sedangkan dari analisis SWOT diketahui bahwa revitalisasi kawasan wisata ecotourism Waduk Darma sudah tepat diterapkan pada wisata ini dengan hasil strenght : berada pada titik strategis, weak : beberapa ruas jalan di kawasan waduk darma tidak memenuhi kriteria, opportunity : terdapat rencana pelebaran jalan, dan threats : Proses pelebaran cukup sulit. Hal ini sesuai dengan hasil kuesioner aksebilitas dilihat dari jalan masuk sebagian besar cukup (50\%), sarana transfortasi Sebagian besar baik (42\%), dan rambu-rambu penunjuk jalan sebagian besar cukup (32\%)

\section{Analisis Wisata}

Sumber daya ekowisata terdiri dari sumber daya alam dan manusia yang dapat diintegrasikan ke dalam satu komponen pemanfaatan pariwisata yang terintegrasi. Ekowisata (Ecotourism, green tourism atau alternative tourism), merupakan wisata berorientasi pada lingkungan untuk menjembatani kepentingan perlindungan sumberdaya alam/lingkungan dan industri kepariwisataan. Pengembangan ekowisata di Waduk Darma adalah dengan membentuk dan mengembangkan kelompok masyarakat pengembang pariwisata (Kompepar) yang melibatkan dari unsur masyarakat setempat sehingga terbentuk masyarakat yang sadar potensi wisata yang ada dilingkungannya tanpa mengubah dan merusak habitat/keadaan/ fungsi alaminya. Sebagai contoh pemanfaatan perairan Waduk Darma untuk sarana wisata berperahu/memancing dengan tetap mempertahankan fungsi waduk sebagai sumber air baku PDAM. Contoh lain adalah dengan membangun track bersepeda dengan memperhatikan aspek lingkungan tanpa merusak mengubah fungsi lahan atau menebang pohon yang sudah berdiri tegak. Waduk Darma jika dilihat dari semua standar dengan kondisi eksisting dilapangan sudah memenuhi kriteria yang ada untuk dijadikan sebuah kawasan wisata ekowisata.

Salah satu daya tarik wisata Waduk Darma yaitu terdapat Pasar Induk Ikan Hias yang berada di Jalan Lingkar Waduk Darma, Desa Bakom, Kecamatan Darma. Letaknya tidak terlalu jauh dari kawasan wisata Waduk Darma. Dikenal dengan berbagai nama, di antaranya Pasar Induk Ikan Hias Bakom atau Pasar Induk Ikan Hias Darma. Pasar ikan hias terbesar di kabupaten Kuningan ini merupakan pusat penjualan ikan hias bagi mVereka yang mempunyai hobi memelihara ikan hias, dan sekaligus diarahkan menjadi pusat oleh-oleh bagi wisatawan yang datang ke Waduk Darma Kuningan. Pasar ikan hias yang buka setiap hari, jam 15.00 sore hingga jam 12.00 malam menyediakan beragam jenis ikan hias baik lokal maupun impor. Ikan Cupang, Koi, Koki, Black Tail dan Red Tail (Cat Fish), Molly, Red Danion, Arwana, Louhan, Komet, Guppy, Manfish dan beragam jenis ikan hias lain dijual satuan, dan ada juga per kantong plastik, isi 3 atau 6 ekor ikan hias. Hari Sabtu dan Minggu biasanya pasar ini ramai dikunjungi pembeli. Pasar Induk Ikan Hias dibentuk atas inisiatif Kelompok Budidaya Ikan (Pokdakan) Tunas Harapan Desa Bakom. Warga Desa Bakom, khususnya para pemuda, dikenal sebagai pembudidaya berbagai jenis ikan hias untuk diperjualbelikan. Pusat penjualan ikan hias ini diresmikan langsung Bupati Kuningan, $\mathrm{H}$ Acep Purnama, pada Desember 2020 lalu. Pasar Induk Ikan Hias Desa Bakom diharapkan dapat menjadi wadah untuk para komunitas budidaya ikan hias serta ke depannya menjadi salah satu sentra ikan hias di Kabupaten Kuningan. 
Hasil dari pembobotan DTW Inskeep akan daya tarik wisata diatas adalah 380, kategori tersebut ada pada standar sedang. Dimana hal ini hampir mendekati sangat berdaya tarik. Wisata Waduk Darma telah memiliki daya tarik bagi para pengunjung yang datang.

Revitalisasi Waduk Darma sejak mulai sampai dengan selesainya revitalisasi tahap pertama memberikan dampak yang positif bagi para pedagang di sekitar objek wisata Waduk Darma. Selama proses revitalisasi, para pedagang dipindahkan sementara sampai proses revitalisasi tahap pertama selesai dan dapat kembali beroperasi. Bangunan warung dibenahi dengan tujuan agar para pedagang maupun pembeli dapat merasa nyaman dalam melakukan proses jual beli di Waduk Darma. Revitalisasi tahap pertama yang dilakukan berjalan dengan sangat baik dan menghasilkan tata ruang yang baik dan teratur terutama warung serta dilengkapi pula dengan sarana dan prasarana yang sangat memadai. Hal ini sesuai dengan hasil kuesioner kepuasan aktifitas wisata dilihat dari menikamti pemandangan sebagian besar cukup nyaman (42\%), mengamati tumbuhan Sebagian besar cukup nyaman (44\%), dan jogging track sebagian besar cukup nyaman $(28 \%)$.

\section{Analisis Best Practice}

Ada 3 Best Practice yang diambil penulis, masing-masing jenis wisata telah sesuai dengan kondisi eksisting dan tambahan improvisasi dari penulis yang cukup serupa dengan keadaan yang ada pada tapak. Best Practices meliputi MacRitchie Reservoir, Waduk Bedok, dan Waduk Jatiluhur. Untuk MacRitchie Reservoir dimasukan dalam zona olahraga dan spillway yang sesuai dengan fungsi dari Waduk Darma saat ini yang kegiatannya didukung oleh area jogging track selain itu zona edukasi juga disesuaikan dengan 2 Best Practice tersebut. Untuk rekreasi penulis memakai Waduk Bedok sebagai Best Practice dari zona rekreasi pada tapak sesuai dengan kondisi eksisting yang cukup serupa. Dan jenis wisata terakhir penulis memilih Waduk Jatiluhur dengan beberapa ruang terbuka sebagai gallery hijau dan sebagai Best Practice penulis dalam melihat berbagai sarana dan atraksi wisata didalamnya. Alasan penulis memilih Waduk Jatiluhur :

a. Kawasan Waduk Darma yang masih memiliki suasana alam yang kental didalamnya

b. Zona Ruang Terbuka Biru (Waduk Darma) yang cukup besar harus dilestarikan dengan menyeimbangkan kesan alam yang ada disekitarnya menggunakan nuansa yang ramah lingkungan dan indah

c. Penulis mengharapkan jenis wisata yang bisa menarik para investor dengan jenis wisata yang mudah mendatangkan pengunjung untuk datang, didukung dengan lokasi dari kawasan yang cukup strategis

d. Kebijakan Pemerintah dalam menetapkan Waduk Darma sebagai daerah wisata dengan nuansa Wisata Alam, dan akhirnya penulis putuskan mengusulkan konsep Ekowisata yang sudah tercantum segala macam jenis wisata yang dapat masuk didalamnya.

Menurut Permendagri No. 33 Tahun 2009. Berikut apa saja failitas yang dibutuhkan untuk kawasan wisata Waduk Darma berdasarkan tapak, diantaranya :

a. Zona Olahraga dan Zona Edukasi

Mencampurkan area wisata dari MacRitchie Reservoir, Waduk Bedok, Waduk Jatiluhur, dimana kebutuhan seperti taman baca, rumah budaya, area jogging track dengan jalur sepeda, bangku taman, area playground, toilet, musholla, gazebo, area pusat perbelanjaan rakyat harus tersedia didalamnya. Khusus bagian edukasi penulis menambahkan sedikit usulan dengan memperhatikan dan mempertahankan fasilitas yang ada didalamnya.

b. Zona Rekreasi

Penulis menggunakan MacRitchie Reservoir menjadi Best Practices bagi zona ini. Wahana, atraksi yang disediakan, took merchant, toilet, café, foodcourt, dsb (Kemendagri, 2009). 
Untuk ketiga Best Practices yang dipilih oleh penulis, dengan jenis wisata yang berbeda namun terintegrasi dalam satu kawasan wisata. Ketiga benchmark akan membantu penulis untuk memberikan usulan kepada kawasan wisata Waduk Darma.

\section{KESIMPULAN DAN SARAN}

\section{Kesimpulan}

Potensi ekowisata di kawasan Waduk Darma berupa panorama alam, pepohonan, areal persawahan, hutan, perairan waduk. Banyak wisatawan berdatangan menikmati ekowisata di area Waduk Darma, dengan melakukan aktivitas seperti berperahu, memancing ikan dan area jogging track untuk berjalan kaki atau bersepeda. Wisata Waduk Darma juga memiliki fasilitas lengkap dan baik seperti wahana anak, cottage, camping ground, dll. Tagline "Pleasant Vacation with Family". Tagline menggunakan Bahasa Inggris karena target audiens yang dituju adalah masyarakat perkotaan. Arti dari taglinenya adalah bahwa Obyek Wisata Waduk Darma merupakan tempat wisata yang nyaman, enjoyable, dan friendly. Setelah dianalisis, terlihat bahwa revitalisasi Waduk Darma lebih memiliki pengaruh yang besar dan positif terhadap kehidupan sosial budaya masyarakat.

Revitalisasi Waduk Darma lebih memiliki pengaruh yang besar dan positif terhadap kehidupan sosial budaya masyarakat, diantaranya : fasilitas pendukung yang dibangun tidak merusak lingkungan dan sesuai dengan karakteristik objek wisata; partisipasi masyarakat dalam melestarikan serta membantu penyediaan jasa pariwisata serta akomodasi penginapan; mengembangkan paket-paket wisata yang mengedepankan budaya dan tradisi lokal sehingga menjadi daya tarik sendiri dan mendukung konservasi budaya local dan; wisatawan dapat menghargai kearifan lokal yang ada di sekitar kawasan wisata Waduk Darma.

Revitalisasi tahap pertama sudah sesuai dengan perencanaan, dengan cukup banyaknya orang yang datang setelah tempat wisata dibuka kembali. Perbandingan kondisi wisata Waduk Darma dahulu dengan sekarang mengalami perbedaan, mulai dari sarana/prasarana pariwisata. Dampak yang ditimbulkan revitalisasi tahap pertama dari segi bangunan menjadi lebih bagus, lebih bersih, lebih nyaman dan lebih indah. Hasil bechmarking dengan objek wisata MacRitchie Reservoir, Waduk Bedok, dan Waduk Jatiluhur Purwakata memiliki beberapa beberapa faktor kesamaan diantaranya : konsep Ekowisata berbasis masyarakat, sama-sama wisata dengan objek waduk, dan terbagi menjadi beberapa zona.

\section{Saran}

a. Untuk Akademis

Penelitian yang akan datang diharapkan menggunakan Kebijakan Pemerintah Provinsi Jawa Barat berkaitan dengan promosi pariwisata, mengetahui proses promosi pariwisata khususnya di Waduk Darma yang menjadi Rencana Kebijakan Pemerintah selanjutnya.

b. Untuk Pemda

Kawasan wisata Waduk Darma sangat mendukung untuk dijadikan kawasan wisata revitalisasi berbasis ekowisata, oleh sebab itu perlu adanya dukungan dari elemen masyarakat dan pemerintah untuk pengembangan dan pengelolaan ekowisata dengan memberdayakan masyarakat peduli ekowisata dengan memberikan penyuluhan tentang potensi wisata yang akan dikembangkan dengan bernegosiasi dengan penduduk setempat. Daya tarik lain yang dimiliki kawasan Waduk Darma sangat banyak, namun yang baru dimunculkan hanya berupa pemandangan alam dan wisata berperahu mengelilingi waduk. Dari pengolahan data kuesioner terdapat beberapa daya tarik lain yang dapat dikembangkan dikawasan waduk yaitu berupa pemancingan, water sport, restaurant terapung, dan lainnya yang berupa kolam renang dan resort. 
c. Untuk Pengembang

Zona Ruang Terbuka Biru (Waduk Darma) yang cukup besar harus dilestarikan dengan menyeimbangkan kesan alam yang ada disekitarnya, menggunakan nuansa yang ramah lingkungan. Perlu penanganan pengelolaan yang sungguh-sungguh dan professional dari pengelola wisata di Waduk Darma.

\section{REFERENSI}

A Yoeti, O. (2014). Pengantar Ilmu Pariwisata. Angkasa Press.

BAPPEDA Provinsi Jawa Barat. (2018). Rencana Strtegis Tahun 2018-2023. Badan Perencanaan Pembangunan Daerah Provinsi Jawa Barat.

Budihardjo, E. \& S. (1989). Konservasi Lingkungan dan Bangunan Kuno Bersejarah di Surakarta, Indonesia. UGM Press.

Damanik, Janianton dan Weber, H. F. (2006). Perencanaan Ekowisata. Pusbar UGM \& Andi Yogyakarta.

Edvardsson, A. dan. (2005). Pemasaran Jasa Prinsip, Penerapan dan Penelitian. Penerbit Andi. Fandeli, C. dkk. (2000). Pengusahaan Ekowisata. Fakultas Kehutanan Universitas Gadjah Mada. Permendagri No. 33 Tahun 2009, (2009).

Undang Undang tentang Kepariwisataan, UU No. 10 Tahun 2009, (2009).

kuninganmass.com. (2020). Revitalisasi Waduk Darma Tahap 2 Segera Dilakukan, Anggaran Ratusan Miliar. https://kuninganmass.com/revitalisasi-waduk-darma-tahap-2-segeradilakukan-anggaran-ratusan-miliar/

Lindberg, K. and D. E. H. (1993). The Ecotourism Society, The Ecotouris Society. Vermont.

META. (2002). Planning for Marine Ecotourism in the UE Atlantic Area. Univ. Of the West England.

Neuman, W. L. (2013). Metodologi Penelitian Sosial Pendekatan Kualitatif dan Kuantitatif (Edisi 7). Indeks.

PDAU Kabupaten Kuningan. (2019). Rencana Revitalisasi Waduk Darma. PDAU Kabupaten Kuningan.

Pemda Kabupaten Kuningan. (2011). Peraturan Daerah Kabupaten Kuningan Nomor 26 Tahun 2011 tentang Rencana Tata Ruang Wilayah (RTRW) Kabupaten Kuningan tahun 20112031.

Pemda Provinsi Jawa Barat. (2020). Waduk Darma Disiapkan sebagai Destinasi Wisata Air Internasional.

https://jabarprov.go.id/index.php/news/39707/Waduk_Darma_Disiapkan_sebagai_Desti nasi_Wisata_Air_Internasional

Pudjiwaskito, D. I. (2005). Kajian pengelolaan dan pengembangan ekowisata sumber air panas Ciater, Subang, Jawa Barat. Fakultas Perikanan dan Ilmu Kelautan. Institut Pertanian Bogor.

Purboseno, S. (2013). Evaluasi Perubahan Tata Guna Lahan sebagai Upaya Menjaga Kerbelanjutan Fungsi Waduk. Ejournal.Undip.Ac.ld, Vol 19 No. https://doi.org/https://doi.org/10.14710/mkts.v19i2.8426

Sugiyono. (2018). Metode Penelitian Kombinasi (Mixed Methods). CV Alfabeta.

Wardani, A. K. (2018). Mendefinisikan Kembali Situ Mustika (Sebuah Analisis Revitalisasi Objek Wisata). Dinamika: Jurnal IImiah Ilmu Administrasi Negara. Universitas Galuh, Vol 5 No 4. https://jurnal.unigal.ac.id/index.php/dinamika/article/view/1747

Yulianda, F. (2007). Ekowisata Bahari sebagai Alternatif Pemanfaatan Sumber daya Pesisir Berbasis Konservasi. 